\title{
PENTINGNYA PERAN ORANGTUA DALAM MEMBENTUK KEPRIBADIAN ANAK
}

\author{
Samsudin \\ Institut Agama Islam Sunan Giri (INSURI) Ponorogo \\ Email; samsu ist@yahoo.co.id
}

\begin{abstract}
The role of parents in the formation of children's personality is very important, in forming the personality of parents must be a figure or give a good example early on, because it can affect the child to grow up to become an adult. The child's personality is formed depending on how parents educate, nurture and apply morals to the child since childhood, so that later in adulthood the child will get used to what is taught by both parents. The formation of the child's personality is not easy for parents, because if parents overestimate the formation of personality and character of children, then children will grow up to become children who often commit fraud, therefore parents must really pay attention to the importance of the formation process the personality of children from an early age and provide a good example also familiarizes with good things so that children grow up to be children who have good personalities and have good characters too.
\end{abstract}

Keywords; The role of parents, children's personality, personality formation.

\section{PENDAHULUAN}

Peran keluarga dalam proses pembentukan kepribadian anak. Sepintas, hal demikian terkesan biasa saja, tetapi jika dipikir lebih mendalam, maka hal tersebut dirasa sangat penting karena dapat berpengaruh terhadap pembentukan karakter anak dimasa dewasa. Pembentukan kepribadian anak dipengaruhi oleh semua unsur lingkungan seperti lingkungan keluarga, lingkungan sekolah, dan lingkungan masyarakat. Akan tetapi, di antara ketiga lingkungan tersebut yang paling berpengaruh adalah lingkungan keluarga, karena dalam di dalamnya semua anggota keluarga dapat salng bersinergi dan saling memengaruhi.

Keluarga adalah persekutuan terkecil yang hidup di masyarakat dan negara. Rumpun anggota keluarga terdiri dari ayah, ibu, anak-anak, dan anggota lain yang tinggal berada di dalamnya seperti pembantu, kakek, nenek, dan keponakan. Lingkungan keluarga bersifat primer dan fundamental, di situlah anak dibesarkan dan memperoleh penemuan awal serta belajar, yang memungkinkan pertumbuhan dan perkembangan diri kepribadian selanjutnya. Dalam lingkungan keluarga anak pertama kalinya memperoleh kesempatan menghayati pergaulan dengan sesama manusia, bahkan memperoleh perlindungan dan kasih sayang yang pertama. Keluarga adalah buaian dari kepribadian atau pusat ketenangan hidup dan pangkalan "home base" yang paling vital lagi menentukan. Keluarga sebagai pusat pendidikan, latihan dan pusat 
kebudayaan serta pusat agama, karena itu hubungan antar anggota keluarga harus selalu harmonis dan terpadu, serta penuh kegotong royongan, kerjasama serta kasih sayang. Setiap anggota keluarga harus merasakan ketenangan, keceriaan, kegembiraan, dan kenyamanan dalam keluarga. Karena itu, pangkal ketenangan dan kedamaian hidup adalah lingkungan keluarga. Mengingat betapa pentingnya hidup dalam lingkungan keluarga demikian, maka Islam memandang keluarga bukan hanya sebagai persekutuan hidup terkecil, tetapi lebih dari itu, yakni sebagai lembaga hidup manusia yang dapat memberikan kemungkinan celaka dan bahagianya anggota-anggota keluarga baik di dunia maupun akhirat. Dengan demikian, keluarga mempunyai peran dan kewajiban yang tidak kecil, kerana baik buruk atau suskses tidaknya anggota keluarga merupakan tangung jawabnya. Ayah sebagai kepala keluarga dan ibu sebagai kepala rumah tangga dituntut untuk mewarnai keluarga dengan nilai-nilai akhlak yang baik, mulia, suri tauladan yang baik, menyelamatkan anggota dari segala bentuk perangai dan perilaku yang tidak baik, dan termasuk dalam pembentukan kepribadian anak. Orangtua merupakan tempat yang paling utama dan pertama dalam proses pembentukan kepribadian anak. Oleh karena itu, supaya dapat membentuk kepribadian anak yang sesuai dengan harapan, maka perlu adanya komunikasi antara kedua orangtua dan anak, karena dengan komunikasi akan mempermudah orangtua untuk mengetahui karakter anak dan mempermudah membentuk kepribadian anak. Dengan komunikasi seksama, dapat mempermudah orangtua untuk mengontrol tingkah laku anak.

Peran keluarga dalam proses pembentukan kepribadian anak sangat besar, keluargalah yang menyiapkan perkembangan kepribadian anak sejak dini. Dengan adanya dorongan dari keluarga, maka dapat membantu anak dalam melakukan penyesuaian yang memuaskan baik itu di masa kini atau di masa mendatang. Pemikiran dan perilaku anak tergantung bagaimana orangtua mendidik. Pembentukan kepribadian anak yang dimulai sejak dini sangatlah penting, karena dapat memengaruhi kehidupan di masa dewasa. Sebagai contoh, seorang anak yang memiliki kepribadian baik akan melakukan perbuatan yang baik juga. Hal itu disebabkan karena peran orangtua dalam membentuk kepribadian anak sejak dini. Menurut (Levine 2005), menyatakan bahwa:

Menjadi orangtua sesungguhnya merupakan proses yang dinamis, situasi keluarga acapkali berubah. Tidak ada yang bersifat mekanis dalam proses tersebut. Akan tetapi, dengan memahami bahwa kepribadian mengaktifkan energi, mengembangkan langkah demi langkah, serta menyadari implikasi setiap langkah terhadap diri anak, para orangtua akan mampu memupuk rasa percaya diri pada diri anak. 
Lalu langkah apa yang harus dilakukan kedua orangtua dalam membentuk kepribadian anak yang baik? Adalah keteladanan orangtua. Dengan kebiasaan yang baik yang dilakukan orangtua, maka anak akan terbiasa dengan hal yang diajarkan kedua orangtuanya. Contoh praktisnya, pertama "seorang bapak atau ibu yang senantiasa menghentikan segala aktivitas ketika mendengar kumandang azan". Jika mendengar kumandang azan, memang sebaiknya istirahat dan menghentikan segala aktivitas. Contoh lain adalah ketika orangtua mengajarkan anaknya untuk selalu mengaji setiap bakda magrib, maka orangtua harus memberikan teladan dulu dengan pembiasaan mengaji. Orangtua mendidik disiplin harus dimulai dengan sikap orangtua yang disiplin dalam berbagai hal.

Kebiasaan demikian jika dilakukan sejak dini, maka akan menjadikan anak bersikap disiplin, karena anak sudah diajarkan orangtuanya terlebih dahulu. Kedua, lihat "kisah keberanian Abdullah bin Zubair". Kisah tersebut menceritakan tentang keberanian Abdullah bin Zubair yang berusia 8 tahun baru masuk Islam, dan ketika umurnya mencapai 12 tahun, dia tersugesti oleh setan bahwa Rusulullah Saw ditangkap di dataran tinggi Makkah. Zubair yang waktu itu berumur 12 tahun keluar rumah sambil menenteng atau membawa pedang. Semua orang terheran termasuk Nabi juga heran melihatnya dan bertanya kepada Zubair "ada apa denganmu wahai Zubair?” Lalu Zubair berkata kepada Nabi, siapa yang berani menangkapmu, maka akan kupenggal kepalanya dengan pedangku ini. Keberanian dari kisah Abdullah bin Zubair yaitu meniru dari pengaruh keberanian ayah dan ibunya" (A'lam an-Nubala, 1/1-42).

Dengan contoh-contoh di atas, maka dapat diperjelas bahwa pembentukan kepribadian anak tergantung pada peran kedua orangtua dalam mengasuh anak dan memberi contoh kebiasaan baik sejak dini. Oleh karena itu, sampai dewasa seorang anak dapat terbiasa dengan segala hal yang sudah diajarkan kedua orangtuanya. Kedua orangtua harus berhati-hati dalam bersikap di depan anak.

\section{METODE}

Penelitian ini dilakukan melalui studi pustaka. Pengumpulan data dengan mengidentifikasi wacana dari buku-buku, makalah atau artikel, jurnal, koran, internet (web), dan informasi lainnya yang berhubungan dengan kepribadian anak. Analisis data menggunakan analisis deskripstif, analisis isi, dan analisis kritis. Analisis deskriptif yaitu mengumpulkan dan menyusun data kemudian data tersebut dianalisis. Analisis isi yaitu memanfaatkan seperangkat prosedur untuk menarik kesimpulan dari sebuah dokumen yang telah diperoleh. Sementara itu, analisis kritis yaitu penafsiran pada teks dan menyikapi makna dibalik peristiwa secara ilmiah. 


\section{HASIL DAN PEMBAHASAN}

\section{Faktor yang Memengaruhi Kepribadian Anak}

Kepribadian adalah sifat bawaan yang dihadiahkan Tuhan pada manusia sejak mereka lahir. Kepribadian yang juga disebut personality dalam bahasa Inggris dibagi ke dalam 4 jenis, yakni "koleris, sanguin, plegmatis, dan melankolis". Kepribadian manusia dapat dipengaruhi dengan beberapa hal, misalnya konsep diri, sifat, lingkungan, fisik, dan lain-lain. Dengan demikian, pribadi manusia dapat diubah. Oleh karena itu, supaya dapat mengubah kepribadian anak, maka ada usaha untuk mendidik anak, membentuk sifat anak. Yang artinya, kepribadian anak dapat diperbaiki, yang mulanya nampak kurang baik menjadi baik. Perkembangan kepribadian anak salah satunya adalah berfikir kritis dan kreatif. Oleh Karena itu perlunya pembinaan dari kedua orangtua kepada anak sejak dini supaya dapat menghasilkan kepribadian anak yang baik.

Adapun yang termasuk faktor dalam diri itu sendiri atau faktor bawaan, ialah segala sesuatu berupa bawaan sejak lahir, baik yang bersifat kejiwaan maupun yang bersifat ketubuhan dan merupakan pengaruh keturunan dari salah satu sifat yang dimiliki oleh kedua orangtuanya. Oleh karena itu, ada istilah "buah jatuh tidak akan jauh dari pohonnya". Kejiwaan seperti perasaan, kemauan, ingatan dan lain-lain yang dibawa sejak lahir dapat berpengaruh pada kepribadian seseorang, sedangkan keadaan jasmanipun seperti susunan urat syaraf, susunan otot, dan keadaan tulang-tulang itu pun juga memengaruhi pribadi manusia.

Selain faktor bawaan atau faktor yang ada dalam diri orang itu sendiri, ada juga faktor dari luar orang tersebut. Faktor dari luar biasanya merupakan pengaruh faktor lingkungan seseorang, mulai dari lingkungan terkecil yaitu keluarga, teman, tetangga, sampai dengan pengaruh dari media televisi, majalah, dan koran. Lingkungan keluarga dapat berpengaruh terhadap kepribadian dan konsep anak sejak kecil. Segala sesuatu yang ada di luar manusia itu sendiri baik itu benda mati ataupun benda hidup. Semuanya berpengaruh pada kepribadian manusia. Selain kedua faktor demikian, terdapat faktor yang memengaruhi kepribadian anak yaitu faktor pengalaman-pengalaman kehidupan anak selanjutnya (pengalaman hidup) atau biasa disebut faktor empiris. Setiap orang mempunyai kehidupan masing-masing, jadi pengalaman yang dialami juga berbeda. Tidak heran kalau sejak kecil walaupun anak sudah dibimbing dengan baik oleh kedua orangtua tetapi ketika dewasa sedikit berbeda dengan yang diajarkan orangtuanya, karena semakin dewasa anak sudah mengalami perubahan-perubahan seperti perubahan fisik dan pengalaman hidup. 
Dari semua faktor yang memengaruhi perkembangan kepribadian anak, keluargalah yang paling penting pengaruhnya. Keluarga merupakan pendidikan pertama bagi anak-anak sejak mereka mengenal dunia. Dalam keluarga, anak akan tumbuh dan berkembang pertama kali sebelum mengenal dunia luar. Dalam hal ini, keluarga berperan penting dalam membentuk dan mengembangkan kepribadian seorang anak. Segala hal yang dilakukan oleh orangtua akan ditiru oleh anak. Oleh sebab itu, biasanya anak disebut sebagai peniru ulung. Keluarga merupakan kelompok sosial yang pertama dikenal oleh anak, dan karena anak lebih menghabiskan waktunya dengan keluarga. Kepribadian orangtua dapat memengaruhi bagaimana orangtua mendidik anak. Jika kepribadian orangtua berpengaruh dalam proses pembentukan kepribadian anak, maka orangtua harus senantiasa mendidik yang baik. Menurut (Hastantyo, 2010) ada sembilan tipe kepribadian orangtua dalam membesarkan anaknya yang berpengaruh pada kepribadian anak, yaitu sebagai berikut:

1. Penasihat moral, terlalu menekankan pada perincian, analisis, dan moral.

2. Penolong, terlalu mengutamakan kebutuhan anak dengan mengabaikan akibat dari tindakan si anak.

3. Pengatur, selalu ingin bekerjasama dengan si anak dan menciptakan tugas-tugas yang akan membantu memperbaiki keadaan.

4. Pemimpi, selalu berupaya untuk berhubungan secara emosional dengan anak-anak dalam setiap keadaan dan mencari solusi kreatif bersama-sama.

5. Pengamat, selalu mencari sudut pandang yang menyeluruh, berupaya mengutamakan objektivitas dan perspektif.

6. Pencemas, selalu melakukan Tanya jawab mental dan terus bertanya-tanya, ragu-ragu dan memiliki gambaran terburuk sampai mereka yakin bahwa anak mereka benar-benar memahami situasi.

7. Penghibur, selalu menerapkan gaya yang lebih santai.

8. Pelindung, enderung untuk mengambil alih tanggung jawab dan bersikap melindungi, berteriak kepada si anak tetapi kemudian melindunginya dari ancaman yang datang.

9. Pendamai, dipengaruhi kepribadian mereka yang selalu menghindar dari konflik.

Selain Sembilan tipe kepribadian orangtua di atas, ada juga Sembilan pilar untuk menumbuhkan kepribadian anak yang berkarakter, menurut (Megawangi, 2004). Sembilan pilar karakter tersebut adalah (1). Cinta Tuhan dan kebenaran. (2). Bertanggung jawab, berdisiplin, dan mandiri. (3). Mempunyai amanah. (4). Bersikap hormat dan santun. (5). Mempunyai rasa kasih sayang, kepedulian, dan mampu kerjasama. (6). Percaya diri, kreatif, dan pantang 
menyerah. (7) .Mempunyai rasa keadilan dan sikap kepemimpinan. (8). Baik dan rendah hati. (9). Mempunyai toleransi dan cinta damai.

Dengan adanya sembilan kebribadian orangtua yang baik, maka orangtua dapat dengan mudah membentuk kepribadian anak dengan baik, seperti adanya sembilan pilar kepribadian anak yang berkarakter. Orangtua dapat membentuk kepribadian anak sesuai dengan sembilan pilar tersebut. Membentuk kepribadian anak sejak dini tidak mudah karena bisa berpengaruh pada masa depan anak. Jika sejak dini anak diajarkan berperilaku tidak baik, maka kelak dewasa anak akan berperilaku yang tidak baik, begitu juga sebaliknya. Oleh karena itu, orangtua harus senantiasa memberikan contoh yang baik pada anak untuk membiasakan perilaku baik. Karena sampai kapanpun, anak akan selalu mengingat tentang segala hal yang diajarkan orangtua di masa kecil.

\section{Pengaruh Lingkungan Keluarga}

Keluarga merupakan lingkungan sosial yang pertama yang memberikan pengaruh sangat besar bagi perkembangan anak. Dimulai dari keluarga lah anak mulai beranjak untuk berinteraksi, menemukan sifat, sikap dan kemampuan dalam membedakan berbagai objek dalam lingkungannya. Oleh karena itu fungsi keluarga yaitu mengembangkan komunikasi dan menyelesaikan masalah-masalah anak, supaya anak merasa diperhatikan oleh orangtuanya dan dengan itu semua jika anak ada suatu masalah maka anak tidak segan untuk membicarakan kepada orangtuanya. Jadi timbullah keterbukaan antara orangtua dan anak dan bisa saling memberi masukan untuk menyelesaikan masalah. Jadi diantara anak dan orangtua dapat saling akrab dan dapat saling membantu. Jika itu dibiasakan sejak kecil maka dapat berpengaruh baik untuk seterusnya.

Lingkungan keluarga sangat penting, terutama adanya kasih sayang dari kedua orangtua. Adanya kasih sayang orangtua itu sangat berpengaruh, karena di masa ini, anak-anak berhadapan dengan orang lain, seperti saudara, guru, teman sebaya. Pada masa ini pula muncullah sifat kemauan dari si anak dan adanya tuntutan dari lingkungan. Di sini, muncullah ketegangan, sifat membandel dari si anak, namun sikap membandel, keras kepala. Pada usia ini dianggap suatu kewajaran karena perkembangan anak. Maka oleh karena itu perlu adanya kasih sayang dari orangtua, dengan memberi kasih sayang itu bertujuan supaya si anak tidak merasa tegang dan setres. Penanaman kebiasaan yang keliru dimasa anak-anak dapat berdampak buruk pada karakter dan kepribadian anak. Kedua orangtua memiliki peran yang penting dalam mewujudkan kepribadian anak. 
Menurut Al-Ghazali, anak merupakan amanah bagi orangtua yang masih suci laksana permata, baik buruknya anak tergantung pada pembinaan orangtua (Syamsul, 2003). Jadi, menjadi orangtua harus memberikan pembinaan, menjaga dan melindungi, memberi kesejahteraan, memberikan pendidikan, dan keterampilan kepada anaknya. Karena dengan itu semua anak bertumbuh kembang dan memiliki kepribadian yang baik. Menanamkan kebiasaan yang baik sejak kecil, maka kelak dewasa dia terbiasa dengan hal yang diajarkan orangtuanya di masa kecil. Si anak juga dapat diterima masyarakat dengan baik, dengan itu semua anak dapat tumbuh menjadi kepribadian yang baik. Sedangkan jika anak sejak kecil mendapatkan kebiasaan yang buruk dari kedua orangtua, maka di kelak dewasa pun dia bisa saja selalu meniru atau mengingat tentang hal yang dibiasakan oleh orangtua sejak kecil dan menjadi kepribadian yang buruk serta tidak diterima masyarakat sekitar karena dari perilaku dan sikap kebiasaannya yang buruk. Contohnya, orangtua memerintahkan kepada si anak "tolong kalau nanti ada tamu yang mencari bapak atau ibu, bilang saja kepada tamu itu kalau bapak atau ibu sedang pergi, bapak dan ibu mau tidur dulu". Dengan diajarkan berbohong hal sepele demikian, maka tertanam pada diri anak sejak kecil maka hingga dewasa. Anak akan terbiasa berbohong dan juga dengan berbagai hal lain yang sifatnya negatif dan mudah ditiru oleh anak.

Peran keluarga sangat berpengaruh dalam pembentukan kepribadian anak. Segala hal yang ditanamkan oleh orangtua sejak kecil sampai dewasa, maka akan terus diingat oleh anak dan dilaksanakan. Dalam keseharian yang lebih banyak berperan mendidik anak adalah ibu. Ibu yang mengandung, yang memberikan ASI, yang mengasuh hampir setiap detik dan setiap saat, maka bisa dikatakan hidup si anak bergantung pada ibu. Dan inilah sebabnya kenapa dikatakan surga anak ada di telapak kaki ibu, yang artinya sebagian dari perilaku anak ditentukan oleh contoh dan perilaku si ibu. Telapak kaki si ibu yang diikuti anak sejak lahir dari belum bisa berjalan sampai sudah bisa berjalan sendiri itu sangat besar pengaruhnya dalam perkembangan pribadi anak.

Supaya anak bisa memiliki kepribadian yang baik, berkarakter, dan sesuai dengan harapan orangtua, orangtua harus mewujudkan kepribadian si anak, yaitu dengan cara: (1). Orangtua harus memberi kasih sayang kepada si anak, dengan kasih sayang yang cukup dari orangtua, maka anak dapat menyelesaikan permasalahan dengan baik. Yaitu dengan membicarakan permasalahan kepada orangtuanya atau si anak dapat menyelesaikannya sesuai dengan apa yang diajarkan oleh orangtuanya. Tetapi jika orangtua selalu menekan anaknya supaya menurut kepada orangtua, maka anak tidak akan memiliki kepribadian yang baik dan sempurna, karena dengan sikap orangtua yang seperti itu dan menyebabkan anak menjadi tidak 
terlalu peka pada lingkungan sekitar dan menjadi penghalang pada pembentukan kepribadian yang sempurna. Contohnya, si anak bisa menjadi anak yang penakut, sulit mencari teman, jarang bermain dengan teman-teman sebayanya. Anak yang seperti itu mungkin karena faktor takut kepada orangtuanya. (2). Diantara kedua orangtua dan anak harus saling menghormati. Saling menghormati berarti sikap orangtua kepada anak harus tegas, supaya anak dapat belajar menghormati orangtua dan orang lain. Jika orangtua memberi contoh baik seperti orangtua mengajarkan kepada anak berbicara dengan orangtua harus sopan dan menggunakan bahasa yang baik, kalau anak lewat di depan orang yang lebih tua darinya, maka harus menundukkan kepala. Meskipun itu kebiasaan yang sepele tapi sangat penting. Jika anak sudah diajarkan seperti itu oleh orangtuanya sejak kecil, maka sampai dewasa pun anak akan terbiasa melakukan hal yang demikian. (3). Kedua orangtua dan anak harus sering berkumpul, dengan sering berkumpul maka diantara orangtua dan anak dapat tumbuh rasa keakraban. Dengan hal demikian, semua orangtua dapat mengetahui sejauh mana pertumbuhan yang terjadi pada anaknya. Dan jika sering berkumpul antara anak dan orangtua, maka akan sering membicarakan sesuatu hal, orangtua mendengarkan kisah anak-anaknya kalau di luar lingkungan keluarga atau mendengarkan masalah yang terjadi kepada anaknya dan orangtua memberikan solusi kepada anaknya supaya anak tidak merasa terbebani dengan masalahnya sendiri. Selain itu, di sini orangtua harus menjelaskan kepada si anak tentang akhlak, hukum fikih, keyakinan, dan kehidupan manusia dan pelajaran-pelajaran yang lain. Selain itu, orangtua juga harus memberikan informasi tentang perubahan fisik yang terjadi pada anaknya serta pertumbuhan anak-anak mereka. (4). Kedua orangtua menjaga ketenangan lingkungan keluarga dan menyiapkan ketenangan jiwa anak-anak. Kedua orangtua harus melakukan itu semua, karena menjaga ketenangan lingkungan keluarga maupun ketenangan jiwa anak-anak itu sangat penting dan berpengaruh pada pertumbuhan potensi dan kreativitas anak. Jika orangtua dapat menjaga itu semua dengan baik, maka perilaku anak tentang keinginan dan kemauan mereka dapat tumbuh menjadi kuat dan hendaknya si anak diberi hak pilih di antara pilihan-pilihan mereka. Orangtua harus mendampingi anak dan memberikan arahan yang baik supaya anak tidak salah pilih terhadap pilihannya. Ketenangan jiwa anak itu sangat penting jika dihadapkan oleh berbagai pilihan, anak akan menggunakan hatinya agar tidak salah mengambil keputusan dan tidak terburu-buru mengambil keputusan. Tetapi jika jiwa anak tidak tenang atau terganggu, maka ketika anak dihadapkan oleh pilihan-pilihan, jiwanya mungkin bingung. Peran orangtua harus selalu mendampingi anak. (5). Mewujudkan kepercayaan, dengan memberikan kepercayaan kepada anak-anaknya berarti samahalnya dengan memberikan penghargaan 
kepada anak. Dengan demikian, anak akan lebih semangat dan juga akan berusaha berani dalam bersikap. Kepercayaan yang timbul pada diri sendiri adalah penyebab mudah menerima kekurangan dan kesalahannya. Dengan memiliki rasa percaya diri, anak akan lebih berani melakukan sesuatu hal, dan itu dapat melatih anak sejak kecil. Contohnya jika anak membantu orang lain, maka anak akan merasa bangga terhadap diri mereka sendiri karena telah melakukan perbuatan baik dan mereka akan sadar tentang keberadaannya telah bermanfaat dan penting bagi orang lain.

Dengan demikian dapat disimpulkan bahwa betapa pentingnya pengaruh peranan keluarga sebagai peletak dasar pola dalam proses pembentukan kepribadian anak. Agar anak mempunyai kepribadian yang baik, orangtua harus memberikan kasih sayang, saling menghormati diantara mereka, mewujudkan kepercayaan pada anak, memberikan ketenangan di lingkungan keluaraga dan ketenangan jiwa anak, sering berkumpul diantara anak dan orangtua. Dengan itu semua, pertumbuhan dan perkembangan kepribadian anak dapat dikendalikan oleh orangtua, supaya orangtua mengetahui sejauh mana pengetahuan yang dimiliki anaknya, memberikan pengarahan yang lebih baik supaya dapat menambah wawasan kepada anaknya dan juga untuk membentuk kepribadian anaknya yang baik dan sempurna.

\section{Peran Keluarga dalam Mendidik dan Membentuk Kepribadian Anak}

Dalam keluarga semua berpengaruh, tapi yang paling besar pengaruhnya adalah ayah dan ibu. Termasuk tugas mendidik anak itu adalah tugas yang paling penting peranannya bagi orangtua, karena itu dapat berpengaruh pada kesuksesan keluarga. Tetapi kesuksesan yang terjadi pada keluarga tidak berarti apapun jika mengalami kegagalan dalam mendidik dan membentuk karakter dan kepribadian anak yang sesuai dengan harapan orangtua.

Sebagian besar waktu anak dihabiskan bersama keluarga. Lingkungan keluarga juga merupakan lingkungan yang utama, oleh karena itu seorang anak bisa mendapatkan dan menerima pendidikan yang sangat besar dimulai dari keluarga. Lingkungan keluarga besar pengaruhnya dalam proses pembentukan kepribadian anak. Menurut (Nazmul Adam, 2011) ada beberapa fungsi keluarga dalam mendidik dan membentuk kepribadian anak, yaitu, (1). Keluarga merupakan lingkungan sebagai pengalaman pertama yang di alami pada masa kanak-kanak, sebagai pengalaman pertama anak, orangtua harus mengetahui bagaimana cara orangtua mendidik dan bersikap kepada anak, orangtua harus membiasakan baik dalam menghadapi segala tingkah laku anak supaya anak merasa kalau dia disayang dan diperhatikan oleh kedua orangtuanya. (2). Anggota keluarga, termasuk kedua orangtua dapat menjamin kehidupan 
emosional anak. Keluarga harus selalu menjaga emosi anak, karena emosi mempunyai pengaruh besar pada kepribadian anak. Emosi juga dapat memengaruhi penilaian orang lain terhadap anak, jika emosi anak tidak dapat dikendalikan maka orang dapat menyimpulkan kalau itu anak nakal dan itu dapat memengaruhi pola penyesuaian anak. Emosi anak yang meningkat sering kali menjadikan anak bersikap kasar, sering murung, dan dapat membuat orang menjadi gelisah serta resah. Oleh karena itu, orangtua harus menjaga emosional anak, supaya anak tidak dinilai orang mempunyai kepribadian yang jelek. (3). Keluarga dapat bertanggungjawab dan saling memberi motivasi dan memberi dorongan supaya anak dapat mencapai keberhasilannya. Dorongan dan motivasi dari orangtua dapat membuat anak tidak mudah putus asa dan anak selalu semangat. Anak tidak akan takut melakukan tindakan apapun jika itu semua sudah didukung oleh orangtuanya. (4). Keluarga dapat meletakkan dasar-dasar pendidikan agama kepada anaknya sejak kecil. Dengan memberikan dasar agama sejak kecil itu sangat baik, karena itu akan memberi bekal kepada anak di dunia dan di akhirat nanti. Jika agama anak kuat, orangtua pasti bangga karena memiliki anak yang mempunyai iman kuat dan tidak mudah menjerumuskan anak kepada hal yang tidak baik seperti kemaksiatan dan sebagainya. (5). Sebagai dasar untuk menanamkan pendidikan moral pada anaknya. Moral di sini berkaitan dengan tingkah laku dan kebiasaan manusia. Jika anak sudah dilatih tentang kebiasaan atau tingkah laku yang baik sejak kecil, maka anak akan terbiasa dengan semua hal demikian, dan menjadi bekal dikelak dewasa nanti. Anak dapat membedakan baik buruknya tindakan yang dilakukan. (6). Sebagai dasar dalam memberikan pendidikan sosial kepada anaknya. Jika anak sudah memasuki lingkungan sosial, maka anak akan mempunyai teman baru, yaitu teman sebayanya. Di sini jika orangtua sudah mendukung anak untuk memasuki lingkup sosial termasuk sekolah, maka anak akan berusaha agar dapat menyenangkan orangtuanya dan anak mulai dapat berpikir supaya dapat diterima oleh temannya. Karena penerimaan dan penolakan dari teman sebayanya dapat memengaruhi keinginan anak, dan mulailah dia untuk mengembangkan sifat-sifat yang dapat disetujui oleh temannya. Jika anak dapat diterima oleh temannya, maka anak merasa percaya diri dan dapat mendapatkan teman yang lebih banyak. Tetapi berbeda pula dengan anak yang tidak diterima oleh temannya, maka anak akan merasa iri, benci karena tidak diajak bermain, mudah tersinggung dan hal sepele apapun dapat meningkatkan amarah mereka. Jika itu terjadi maka itu tentu saja tidak dapat membantu mereka untuk mengembangkan kepribadian sosial mereka. Kepribadian mereka akan tumbuh menjadi kepribadian yang buruk. Faktor penerimaan sosial sangat penting pengaruhnya pada pribadi anak. (7). Menjaga kesehatan anak supaya anak dapat dengan nyaman menjalankan proses 
belajar yang utuh. Kesehatan juga berpengaruh, karena jika keadaan anak sedang sakit, maka kalau belajar pasti merasa tidak nyaman dan malas. (8). Memberikan anak kesempatan untuk belajar dengan cara mengenalkan ilmu pengetahuan. (9). Hendaknya orangtua memberikan pendidikan agama kepada anak agar mendapatkan kebahagiaan di dunia dan di akhirat sebagai tujuan akhir manusia.

\section{KESIMPULAN}

Lingkungan keluarga merupakan lingkungan yang pertama dikenal oleh anak. Anak menghabiskan waktu dengan keluarga. Di lingkungan keluarga, orangtua mempunyai peran penting dalam pembentukan kepribadian anak, karena segala hal yang menjadi kebiasaan orangtua dapat ditiru oleh anak. Orangtua merupakan figur bagi anak, karena orangtualah yang mengasu dan mendidik anak sejak kecil. Kepribadian anak tergantung bagaimana orangtua mendidik dan membiasakan anak tersebut. Jika peran orangtua dalam mendidik anak benar, maka anak dapat tumbuh menjadi anak yang mempunyai kepribadian dan karakter yang baik. Menjadi orangtua harus benar-benar memperhatikan tumbuh kembang anak serta memperhatikan proses perkembangan anak, terutama memberi teladan yang baik.

\section{ACKNOWLEDGEMENT}

Terimakasih penelti haturkan kepada segenap civitas akademika INSURI Ponorogo terutama segenap dosen yang mengampu di Program Studi Pendidikan Agama Islam (PAI). Karena dengan bantuannya, peneliti mampu merampungkan penelitian ini dengan baik. Kajian dan diskusi yang telah diberikan sangat memberi arti kepada peneliti guna mengembangkan kompleksitas kepenulisan karya ilmiah. Penelitian ini merupakan penelitian individu yang peneliti tulis tanpa mendapat biaya dari luar. Penelitian ini dilakukan guna memenuhi kewajiban salah satu tridarma perguruan tinggi yaitu meneliti.

\section{BIBLIOGRAFI}

Gunarsa, Singgih D. 2001. Menyikapi Periode Kritis Pada anak dan Dampaknya pada Profil Kepribadian tahun 2001 dalam Psikologi Perkembangan Pribadi dari Bayi sampai Lanjut Usia. Editor: S.C. Utami Munandar. UI Press.

Hastantyo. 2010. Peranan Keluarga Dalam Membentuk Kepribadian Anak. Bumi Aksara Hurlock, Elizabeth B. 1978. Perkembangan Anak. translated by Tjandrasa, M. Erlangga. Nazmul, Adam. 2011. Peranan Orangtua dalam Membentuk Kepribadian Anak. Rineka Cipta 
Sjarkawi. 2006. Pembentukan Kepribadian Anak. PT Bumi Aksara.

Sujanto, A, dkk. 2006. Psikologi Kepribadian. PT Bumi Aksara.

SumardiSuryabrata. 1986, Psikologi Kepribadian, edisi 3. Rajawali Press. 